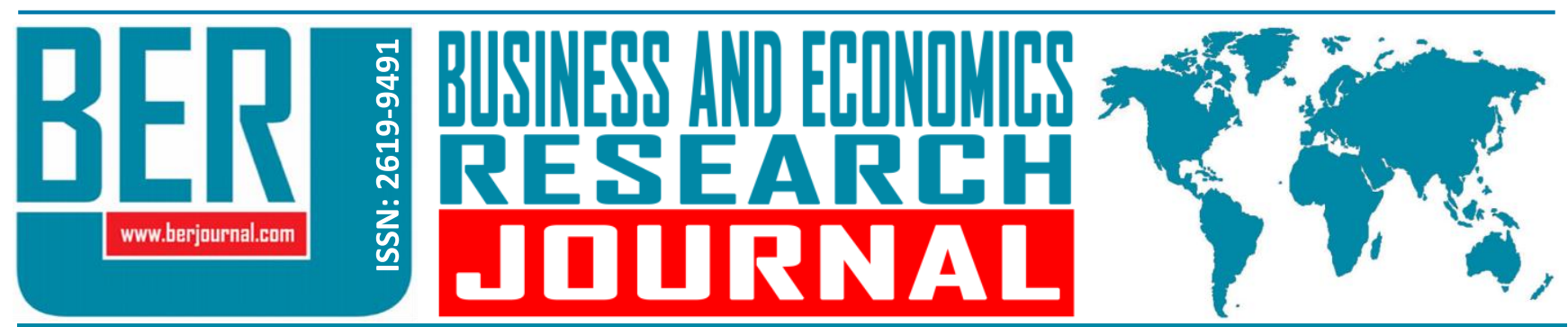

Business and Economics Research Journal Vol. 10, No. 2, 2019, pp. 483-497 doi: 10.20409/berj.2019.181

\title{
Örgütsel Stres Algısında Cinsiyet Temelli Farklılıklar ve Stres Kaynakları Üzerine Bir Araştırma
}

\section{Kurtulus Kaymaz}

Öz: Araştırma, örgütsel stres algısının ve stres faktörlerinin cinsiyet temelinde farklılık gösterip göstermediğini ortaya koymayı amaçlamaktadır. Bu amaçla, literatürde talepkontrol-destek modeli olarak ifade edilen yapı esas alınmış, modelde yer alan üç alt boyuta (iş yükü, karar verme ve sosyal destek) ilişkin veriler toplanmış ve bu çerçevede analizler yürütülmüştür. Veriler, yüz yüze anket yöntemiyle toplanmıştır. Çalışma, 2467 çalışan üzerinde başlatılmış, 1922 kişiden geri dönüş sağlanmıştır. Araştırmada öne çıkan ilk temel bulgu, çalışanların önemli bir kısmının "yüksek işstresi" bölgesinde faaliyetlerini yürütüyor olmalarıdır. Diğer taraftan, iş yükü ve karar verme alt boyutları itibariyle kadın ve erkek çalışanlar arasında algı farklılıklarının olduğu tespit edilmiștir. Buna karşın, sosyal destek boyutunda cinsiyet yönüyle herhangi bir anlamlı farklılığa rastlanmamıştır. Stres kaynakları açısından, ücret ve sosyal haklar, yönetici tutum ve davranışları ile fiziksel çalışma koşullarındaki olumsuzlukların, hem erkek hem de kadın çalışanlarda en belirgin stres faktörleri olduğu bulgusuna ulaşılmıştır. Özellikle, kadın çalışanların, erkek çalışanlara göre fiziksel çalışma koşullarındaki olumsuzluklardan, iş yükü dengesizliklerinden, iş sağlığı ve güvenliği tedbirlerindeki eksikliklerden, çalışma molalarındaki uygulamalardan ve yıllık izin kullanımındaki olumsuzluklardan daha fazla negatif yönde etkilendiği sonucuna varılmıştır.

\section{A Research on Gender Based Differences in Perceived Organizational Stress and Stress Sources}

\begin{abstract}
The research is aimed to investigate if the perceived organizational stress and stress sources differ according to gender. For this purpose, the demand-control-social support model was used and data were collected via face to face survey around three subdimensions (work load, decision, and social support). The study is conducted on totally 2467 employees and 1922 employees were responsive. The fist main finding of this study is that the important part of the employees were working in "high job stress" region. Another finding in the research show that there is a significant difference between male and female employees from the point of work load and decision (autonomy). Conversely, it is found that gender of the employees does not form a significant difference for social support dimension. From the perspective of stress sources, the findings indicate that negative circumstances in pay and social rights, managers' attitudes and behaviors and physical working conditions are main stress sources for both males and females. Especially, results proved that females affected more negatively from the stress sources like physical working conditions, work load, occupational health and safety, working breaks and annual leave than males.
\end{abstract}

Anahtar Sözcükler: Örgütsel Stres, İş Yükü, Karar Verme, Örgütsel Destek, Stres Kaynakları

JEL: J24, J28, M14, M54, 015

$\begin{array}{ll}\text { Geliş } & : 22 \text { Kasım } 2018 \\ \text { Düzeltme } & : 17 \text { Ocak } 2019 \\ \text { Kabul } & : 11 \text { Şubat 2019 } \\ & \text { Tür }\end{array}$

Keywords: Organizational Stress, Work Load, Decision Making, Organizational Support, Stress Sources

JEL: J24, J28, M14, M54, 015

Received : 22 October 2018

Revised : 17 January 2019

Accepted : 11 February 2019

Type : Research 


\section{Giriş}

Artan örgütsel stres, iş yaşamında en fazla mücadele edilen konulardan biri haline gelmiştir. Modern örgütler, teknoloji, yüksek iş kapasitesi ve hıza dayalı üretim nedeniyle yüksek düzeyde stres potansiyeli göstermektedir (Barboza ve Thomas, 2017). Bu araştırmanın amacı, örgütlerde önemi artan stres olgusunun kadın ve erkek çalışanlar bazında gösterdiği farklılıkları ortaya koymak ve olası stres kaynaklarının cinsiyet bazındaki yansımalarını tartışmaktır. Kadın ve erkeklerin stres algısı ve strese karşı olan reaksiyonları farklıık gösterebildiği için bu araştırmada katılımcıların kadın ve erkek olma nitelikleri tartışmanın ana eksenini şekillendirmektedir.

Illgili literatür (Eisler ve Blalock, 1991; Efthim vd., 2001), "sosyal beklentilerin" stres ve strese bağ।ı ortaya çıkan psikolojik etkilere gösterilen tepkilerin belirleyicilerinden biri olduğunu ifade etmekte, bu bağlamda kadın ve erkeklerin farklılaşan sosyal beklentilerinin strese karşı reaksiyonlarını ve stresle mücadele biçimlerini farklılaştırdığını ortaya koymaktadır. Bu bağlamda Selye (1976), stresi kişinin dinamik bir çevrede karşı karşıya kaldığı fırsat, kısıtlı durum ya da talep olarak tanımlamaktadır. Bu durumda örgütsel stresi, birey ile örgüt çevresi arasındaki uyumsuzluk hali olarak değerlendirmek mümkündür (Chaturvedi, 2011). Bireyi cinsiyet temelinde ele alıp, örgütsel çevre ile uyumsuzluğuna, diğer bir deyimle stres olgusuna olan reaksiyonunu değerlendiren çeşitli araştırmalara rastlamak mümkündür. Calvarese'in (2015) üniversite öğrencileri üzerinde gerçekleştirdiği araştırmada, kadın ve erkeklerin strese karşı reaksiyonlarında anlamlı bir farklılığın olduğunu ortaya koyan ampirik sonuçlara varmıştır. Bu çerçevede, araştırmada strese maruz kalındığında, kadınların erkeklere göre daha fazla depresyon, hayal kırıklığı ve kaygı yaşadıkları bulgulanmıştır. Diğer taraftan stres, örgütsel düzeyde performans kavramı ile de ilişkilendirilmektedir. Stresin, belirli bir düzeye kadar performans artışını sağladığı bilinse de (Türkmen, 2015), stresin kadın ve erkeklerde rekabet etme istekliliğini azalttığı ifade edilmektedir (Cahlikova vd., 2016). Cahlikova, ulaşılan bulgular çerçevesinde kadınların stres altında performanslarının düştüğünü ortaya koyarken, erkeklerde stresin performansı etkileyen bir değişken olduğuna dair kanıtlara rastlamamıştır. Bu noktada vurgulanmak istenen, stres algısının ya da strese karşı reaksiyonların cinsiyet bazında farklılaşabildiğidir. Stres faktörlerine olan yaklaşımın, cinsiyet temelinde farklılaşabildiği konusu çalışmanın ilerleyen kısımlarında çeşitli akademik çalışmalara atıfta bulunularak tekrar değerlendirilecektir.

\section{Talep-Kontrol-Destek Modeli}

Araştırmanın başlangıç noktasını, Karasek (1979) tarafından geliştirilen talep-kontrol modeli oluşturmaktadır. Karasek, iş ortamındaki gerginliğin çalışma ortamındaki tek bir ölçüte bağlanamayacağını, kişinin çalışma durumuna göre talepleri ve söz konusu taleplere ulaşabilmesini sağlayacak karar alma inisiyatifinin (kontrol) birleşimi ile şekillendiğini öne sürmektedir. Bu amaçla Şekil 1'de görülmekte olan yapıyı geliştirmiştir. Bu yapı yardımı ile Karasek, talep ve karar alma eylemleri arasında farklı kombinasyonlar yaratarak işlerin sınıflandırabileceğini ifade etmektedir. Modelde, (A) talep ve karar alma süreçlerinin ayrıştığı durumu ifade ederken, (B) farklı talep ve karar alma durumlarıyla eşleşen işleri nitelemektedir. illk durumda (A), işle bağlantılı talep, karar alma inisiyatifinden göreli olarak fazladır ve zihinsel gerginliğin mevcut olduğuna işaret etmektedir. Diğer bir deyimle, (A) durumunda iş ile ilişkili talepler artıp, karar alma inisiyatifi azalınca stresin artacağı öne sürülmektedir. Bu noktada, ortaya çıkan gergin koşullar ile başa çıkabilecek yeteneklerin varlığı halinde kişinin yetkinliğinin artacağı belirtilmektedir. Talep ve karar alma inisiyatifinin yüksek olduğu işler "aktif" iş sınıfına alınmakta, söz konusu iş sınıfının işte veya iş dışında yeni davranış gelişimine öncülük edeceği varsayılmaktadır. Tam tersi durumda, işlerin "pasif" iş sınıfında yer alacağı belirtilmekte ve problem çözme becerisinin düşeceği öngörülmektedir. Sonraki aşamalarda, talep-kontrol modeline üçüncü bir değişken olarak "sosyal destek" boyutu eklenmiştir (Karasek vd., 1982; Karasek ve Theorell, 1990). Ortaya çıkan yeni modelde (talep-kontrol-destek modeli), talebin yüksek, kontrol ya da karar verme inisiyatifinin ve sosyal desteğin düşük olduğu koşullarda işte gerginliğin yüksek olacağı ifade edilmektedir. Karasek ve meslektaşlarının 1982 yılında yürütmüş oldukları çalışmada, sosyal destek faktörünün işteki gerilim üzerine etkileri aynı düzeydeki iş arkadaşları ve yöneticiler bazında olmak üzere ayrıntıları ile tartışılmaktadır. Diğer taraftan (Rodriguez vd., 2001), başkalarından sağlanan sosyal desteğin, işte karşılaşılan stresi ve buna bağlı ortaya çıkan olumsuz sonuçları engelleyen bir etkide bulunduğu ifade 
edilmektedir. Aynı çalışmada, sosyal desteğin strese neden olan faktörler ile stresin yol açtığı sonuçlar arasındaki ilişkide aracı rol üstlendiği de ayrıca vurgulanmaktadır.

Şekil 1. İşte Gerginlik (Talep-Kontrol) Modeli

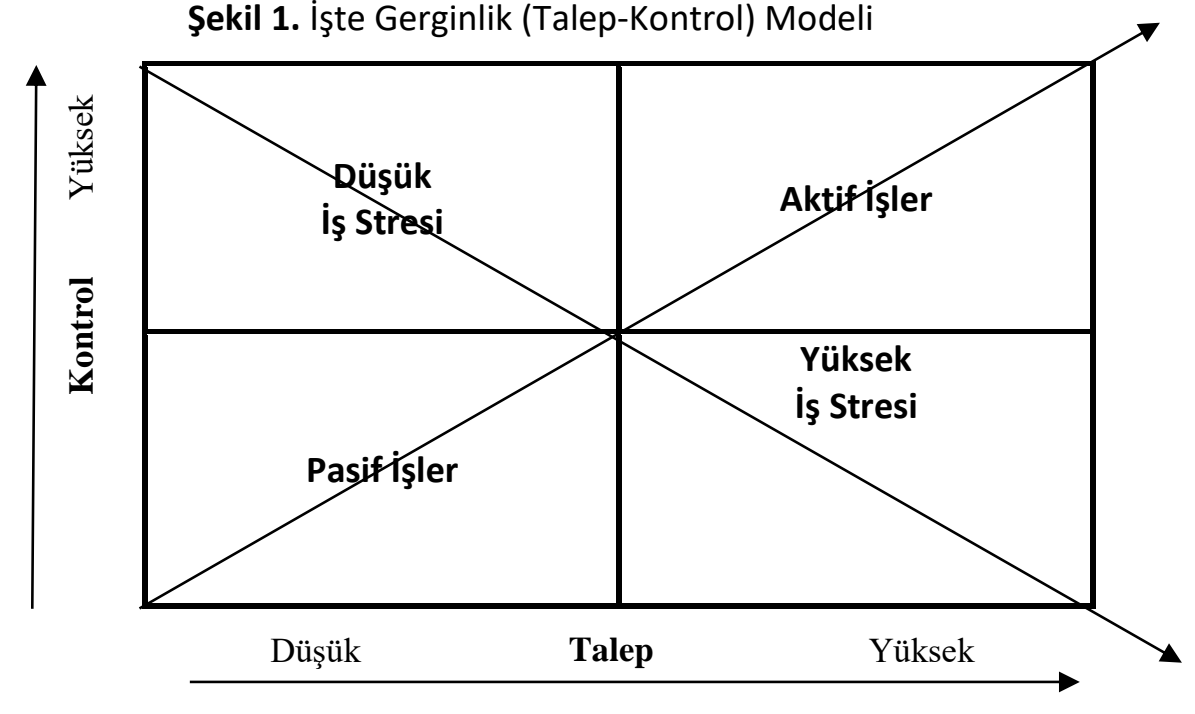

\section{3. Örgütsel Stres-Cinsiyet Ilişkisi}

İlgili yazında, örgütsel stresin cinsiyet bazında nasıl algılandığını ve nasıl reaksiyon gösterildiğini ortaya koyan çeşitli araştırmalara (Lim ve Teo, 1996; Vagg vd., 2002; Wu ve Shih, 2010; Torres vd., 2013; Tandon vd., 2014; Tanrıkulu, 2017) rastlamak mümkündür. Bazı araştırmalarda örgütsel stres kaynaklarına dönük algının ve oluşan reaksiyonların, cinsiyet temelinde farklılaştığı öne sürülürken, birtakım araştırmalarda söz konusu algı ve reaksiyon farklılıklarının var olmadığı dile getirilmektedir. Tinuke (2015) tarafından, eğitim, sağlık ve medya kuruluşlarında görevli toplam 300 çalışan üzerinde gerçekleştirilen bir araştırmanın sonuçları, strese neden olan faktörler ve bu kapsamda gösterilen reaksiyonlar açısından kadın ve erkek çalışanlar arasında anlamlı farklılıkların olduğunu göstermektedir. Çalışmada ulaşılan bulgular, bir yandan hem kadınların hem de erkeklerin, örgütsel stresin işte dikkati olumsuz yönde etkilediği yönünde ortak algılaması olduğunu ortaya koyarken, diğer yandan stres faktörlerinin, daha düşük hiyerarşik kademelerde çalışan kadınları erkeklere nazaran daha derinden etkilediğini doğrulamaktadır. Bir başka çalışmada (Mallach, 1996), kadın ve erkeklerin stres faktörleri ile mücadelede gösterdikleri tutumlar araştırılmaktadır. Söz konusu araştırmada, kadın ve erkeklerin stresle mücadeledeki tutumlarının tüm stres faktörleri bazında aynı olmadığı ve kadınların erkeklere göre örgütsel stresle mücadelede daha etkin oldukları bulgusuna ulaşılmıştır.

Benzer biçimde, 22 farklı ülkeden elde edilen bir örneklem üzerinden kültürlerarası bir karşılaştırma sunan diğer bir araştırmada (Miller vd., 2000), stres kaynaklarının değerlendirilmesinde cinsiyet bazında bir algı farklılığının olmadığı, buna karşın stresin yarattığı sonuçlar yönüyle kadın ve erkekler arasında anlamlı bir algı farklılığın olduğu sonucuna ulaşılmışır. Örgütsel stres bağlamında, çeşitli meslek grupları arasında karşılaştırmalar yapan ve cinsiyet bazında çıkarımlarda bulunan Narayahan vd. (1999), stres algısının kadın ve erkekler bazında farklılaştığını ortaya koyan bulgulara ulaşmışlardır. Çalışmada, kişiler arası çatışmanın erkeklere nazaran, kadınlar arasında daha fazla stres faktörü olarak değerlendirildiği belirtilmektedir. Özellikle satış türü işlerin yürütüldüğü pozisyonlarda, erkeklerin problemi doğrudan çözmeye odaklanarak stresle mücadele ettikleri, kadınların ise stres düzeylerini daha çok konuşarak azaltmaya çalıştıkları belirtilmektedir. Buna karşın, daha yüksek nitelik gerektiren işlerde (akademisyenlik vb.) hem kadınların hem de erkeklerin çözüm odaklı davranışlarla stresi azaltmaya gayret gösterdikleri ifade edilmektedir. Omolayo (2012) tarafından polis memurları üzerinde gerçekleştirilen bir diğer araştırmanın sonuçları, kadın polis memurlarının erkeklere göre daha yüksek düzeyde stres altında olduklarını ortaya koymaktadır. İşyerinde sapkın davranışlar, iş tatmini, kişilik ve cinsiyet değişkenleri arasındaki ilişkilerin analiz edildiği diğer bir çalışmada ise (Santos ve Eger, 2014) örgütsel stresin işyerinde sapkın davranışları tetiklediği ve erkeklerin 
kadınlara nazaran daha fazla sapkın davranışlar sergilediği ortaya konmaktadır. Bir başka araştırmada Sliskovic ve Sersic (2011), 1168 üniversite öğretim üyesi üzerinde bir araştırma gerçekleştirmiş ve iş yükü, teknik koşullar, iş arkadaşları ile ilişkiler, öğrenciler, örgütsel yapı ve ödüllendirme sistemi bazında ortaya çıkan stres faktörlerinin, kadın ve erkek öğretim üyeleri arasında anlamlı bir farklılık gösterip göstermediğine odaklanmışlardır. Bulgular, kadın öğretim üyelerinin erkek öğretim üyelerine nazaran daha fazla stres altında olduklarını ortaya koymuştur. Benzer biçimde Shen de (2014), örgütsel stres algısının cinsiyet temelinde farklılaştığı noktasında çeşitli bulgulara ulaşmıştır.

Buna karşın, Gelyllensten ve Palmer (2005) stres faktörlerine ait algının (ayrımclık, kariyer yollarında ilerleme güçlükleri, çoklu rollerin varlı̆ıı) kadın ve erkekler arasında anlamlı bir farklılık gösterdiğine dair somut kanıtlara ulaşamamışlardır. Doktorlar üzerinde gerçekleştirilen bir başka çalışmada (Rout, 1999), zaman baskısı, çalışma koşulları, iletişim, kariyer gelişimi ve hedefler üzerinden ortaya çıkan stres faktörlerinin, kadın ve erkek doktorlar üzerindeki etkileri saptanmaya çalışılmıştır. Araştırmada, stres faktörlerine dönük algının, kadın ve erkek doktorlar bazında temel bir ayrışma göstermediği tespit edilmiştir.

\section{Metot, Ölçme Aracı ve Temel Hipotezler}

Veriler, yüz yüze anket yöntemi kullanılarak toplanmıştır. Veri toplama aşamasına geçmeden önce ölçekte yer alan ifadeler, kurum insan kaynakları departmanı ile gözden geçirilmiştir. Buna ilave olarak, söz konusu ölçek kurum üst düzey yöneticileriyle de paylaşımış, gerekli geribildirimler alınmıştır. Bu sayede, ifadelerin kurum çalışanları açısından uygunluğu test edilmiştir. Sonraki aşamada, kurum bünyesinde yapılan bir planlama ile toplam 2467 çalışan üzerinde çalışma başlatılmış, 4 gün içerisinde 1922 kişi ile yüz yüze anket çalışması gerçekleştirilmiştir. Araştırmaya, yöneticiler, idari personel ve mavi yakalıların tümü dâhil edilmiştir. İzin, mazeret, hastalık veya günlük iş temposu nedeniyle 545 çalışan anket uygulamasına katılamamıştır. Bu bağlamda, anketin geri dönüş oranı \%78 düzeyindedir. Geri dönüş alınan anketlerden 15 adedi, kayıp verilerin yoğunluğu nedeniyle analiz kapsamı dışında tutulmuştur. Nihai olarak 1907 adet anket üzerinden analiz çalışmaları yürütülmüştür.

Araştırma, Robert Karasek (1979) tarafından, örgüt düzeyinde stres ölçümüne dönük geliştirilen iki boyutlu model (Talep-Kontrol Modeli) ve sonrasında Johnson (1988) tarafından stres ölçümlemesini güçlendirmek için eklenen "Sosyal Destek" boyutunu da kapsayacak biçimde tasarlanmıştır. Aynı yıl (1988) Töres Theorell, Karasek' in 49 ifadeden oluşan anketinin "kısa versiyonunu" oluşturmuş, 17 ifadeden meydana gelen yeni bir ölçek geliştirmiştir. Theorell'in geliştirdiği ölçek daha sonra Türkçe literatüre kazandırılmıştır (Yıldırım vd., 2011; Cronbach Alpha 0,79). Bu araştırmada, Theorell tarafından geliştirilen kısa versiyon örgütsel stres ölçeği kullanılmıştır. Örgütsel stres ölçeği, psikolojik talep (5 ifade), kontrol (6 ifade) ve sosyal destek ( 6 ifade) olmak üzere 3 alt boyuttan oluşmaktadır. Ölçek, tarafımızdan faktör analizine tabi tutulmuş ve analize hazır hale getirilmiştir. Araştırmada, katılımcıların farklı düzeydeki tutumlarını saptamak amacıyla 5'li Likert ölçeği kullanılmıştır. Ölçekte, 3 alt boyuttan iş yükü ve kontrol boyutu için [Hiçbir Zaman (1)-Çok Nadir (2), Bazen (3), Çoğu Zaman (4), Her Zaman (5)] skalası kullanılırken, üçüncü boyut olan sosyal destek için [Kesinlikle Katılmıyorum (1) - Kesinlikle Katılıyorum (5)] skalasına yer verilmiştir.

Ölçekte ayrıca, strese neden olan faktörlerin neler olabileceği de sorgulanmıştır. Bu çerçevede, anketin sonuna açık uçlu bir soru eklenmiştir. Bu soru vasıtası ile çalışanların iş tatmin düzeylerini doğrudan etkilediği düşünülen ve dolaylı olarak strese neden olabilecek nitelikte ipuçların edinilmesi amaçlanmıştır. Toplam 690 çalışan açık uçlu soru yardımıyla düşüncelerini yazılı olarak ifade etmiştir. Yapılan değerlendirmelerde, nitel değerlendirme için 640 anketin kullanışlı veri içerdiği görülmüştür.

Araştırmada, esas olarak üç ana soruya yanıt aranmaktadır. Birincisi, araştırma kapsamına alınan çalışanlar, talep-kontrol modeli çerçevesinde, yüksek ve düşük iş stresi bölgelerinde nasıl bir dağılım göstermektedirler? Yüksek iş stresi bölgesinde yer alan kadın ve erkek çalışanların genel profili nedir? ikincisi, örgütsel stres algısı tüm ölçek ve alt boyutlar bazında, kadın ve erkek çalışanlar arasında anlamlı bir farklılık göstermekte midir? Bu soru için aşağıdaki hipotezler test edilmiştir. Üçüncüsü ise kadın ve erkek çalışanlar açısından stres yaratan faktörler nelerdir? 
H1: Örgütsel stres algısı cinsiyet itibariyle anlamlı bir farklılık göstermektedir.

H2: İ̧ yükü algısı cinsiyet itibariyle anlamlı bir farklılık göstermektedir.

H3: Karar verme algısı cinsiyet itibariyle anlamlı bir farklılık göstermektedir.

H4: Sosyal destek algısı cinsiyet itibariyle anlamlı bir farklılık göstermektedir.

\section{Bulgular}

\subsection{Katılımcıların Demografik Profili}

Ankette cevaplayıcıların demografik özelliklerinin tespitine yönelik 4 ifadeye (cinsiyet, yaş, eğitim, kıdem) yer verilmiştir. Örneklemin demografik profili Tablo 1'de görülmektedir. Araştırma özellikle kadın ve erkek temelinde karşılaştırmalı olarak kurgulandığı için cinsiyet verilerinin oransal dağılımı hassasiyet taşımaktadır. Bu bağlamda, araştırma kapsamına alınan kadın çalışanların oranı \%53,1 erkek çalışanların oranı ise \%41,6 seviyesindedir. Analiz açısından kadın ve erkek çalışanların hemen hemen eşit oranda araştırmaya dâhil edildikleri söylenebilmektedir. Bu durum, verilerin yorumlanmasında yanlı bir değerlendirmenin yapılmasını engellemektedir.

Tablo 1. Katılımcıların Demografik Özellikleri

\begin{tabular}{|c|c|c|c|}
\hline & & $\mathbf{N}$ & (\%) \\
\hline \multirow{3}{*}{ Cinsiyet } & Kadın & 1012 & 53,1 \\
\hline & Erkek & 794 & 41,6 \\
\hline & Cevapsiz & 101 & 5,3 \\
\hline \multirow{6}{*}{ Yaş } & 20 yaşına kadar & 3 & 0,3 \\
\hline & 21-30 yaş arası & 361 & 18,9 \\
\hline & 31-40 yaş arası & 714 & 37,4 \\
\hline & 41-50 yaş arası & 719 & 37,7 \\
\hline & 51 yaş ve üstü & 66 & 3,5 \\
\hline & Cevapsız & 41 & 2,1 \\
\hline \multirow{6}{*}{ Kıdem } & 1 yıla kadar & 326 & 17,1 \\
\hline & 1-5 yıl arası & 330 & 17,3 \\
\hline & 6-10 yıl arası & 239 & 12,5 \\
\hline & $11-15$ yıl arası & 219 & 11,5 \\
\hline & 16 yıl ve üstü & 712 & 37,3 \\
\hline & Cevapsiz & 81 & 4,2 \\
\hline \multirow{7}{*}{ Eğitim } & ilkokul-Ortaokul (ilköğretim) & 741 & 38,9 \\
\hline & Lise & 789 & 41,4 \\
\hline & Meslek Yüksek Okulu & 102 & 5,3 \\
\hline & Üniversite (Lisans) & 223 & 11,7 \\
\hline & Yüksek Lisans & 19 & 1,0 \\
\hline & Doktora & 1 & 0,1 \\
\hline & Cevapsiz & 32 & 1,7 \\
\hline
\end{tabular}

Analize geçmeden önce verilerin normal dağılıp dağılmadığı test edilmiştir. Normallik testi sonuçlarına bakıldığında (Tablo 2), araştırmada kullanılan alt ölçek boyutlarına ait çarpıklık ve basıkık değerlerinin genel olarak -1 ile +1 arasında yer aldığını görmek mümkündür. Çarpıklık ve basıklık değerlerinin, -1 ile +1 arasında yer alması halinde normallik varsayımının karşılandığı ifade edilmektedir (Kalaycı, 2005: 73). Bu noktadan hareketle, alt ölçeklerin genel olarak kabul edilebilir limitler arasında normallik varsayımını karşıladığı tespit edilmiştir. Örgütsel stres ölçeği alt boyutlarına ait çarpıklık ve basıklık değerleri, ortalamalar ve standart sapma değerleri Tablo 2'de görülmektedir. 
Tablo 2. Örgütsel Stres Ölçeği Alt Boyutları Bazında Ortalama, Standart Sapma, Çarpıklık Ve Basıklık Değerleri

\begin{tabular}{lccccc}
\hline \hline & $\mathrm{N}$ & Ortalama & $\begin{array}{c}\text { Standart } \\
\text { Sapma }\end{array}$ & $\begin{array}{c}\text { Çarpıklık } \\
\text { Derecesi }\end{array}$ & $\begin{array}{c}\text { Basıklık } \\
\text { Derecesi }\end{array}$ \\
\hline iş Yükü & 1907 & 3,75 & 0,50 & $-0,291$ & 0,821 \\
Karar Verme & 1907 & 3,44 & 0,67 & $-0,205$ & $-0,248$ \\
Sosyal Destek & 1907 & 3,71 & 0,71 & $-0,760$ & 1,253 \\
\hline \hline
\end{tabular}

\subsection{Açıklayıcı Faktör Analizi}

Araştırmada, Temel Bileşenler Analizi (Principal Components Analysis-PCA) "Varimax Rotation" Metodu ile faktör analizi uygulanmıştır. KMO ve Bartlett Test sonucu $(0,758, \chi 2=7004,391 ; d f=66 ; p=0,000)$, verilerin bir faktör analizi için uygun olduğunu ortaya koymaktadır. Tüm ifadelerin öz değeri 1'den büyük 3 boyut altında toplandığı görülmüştür. 3 boyut için toplam açıklanan varyans $\% 61,4$ seviyesindedir. Faktör yük değerleri 0,40'ın altında kalan ifadeler ölçekten çıkarılmıştır.

Tablo 3. Açıklayıcı Faktör Analizi Sonuçları

\begin{tabular}{|c|c|c|c|c|}
\hline \multirow[b]{2}{*}{ ifadeler } & \multicolumn{4}{|c|}{ Faktör Yükleri } \\
\hline & 1 & 2 & 3 & $\begin{array}{c}\text { Cronbach } \\
\text { Alpha }\end{array}$ \\
\hline İş Yükü & & & & 0,81 \\
\hline 1.Çok hızı mı çalışmak zorundasın? & ,839 & & & \\
\hline 2.Çok yoğun mu çalışmak zorundasın? & ,860 & & & \\
\hline 3.Yaptığın iş çok fazla çaba gerektirir mi? & ,746 & & & \\
\hline Karar Verme & & & & 0,68 \\
\hline 4.Yaptığın iş inisiyatif almanı gerektiriyor mu? & & ,431 & & \\
\hline 5.İşinde nasıl çalışacağının kararını kendin verebiliyor musun? & & 755 & & \\
\hline 6.İşinde ne yapacağının kararını kendin verebiliyor musun? & & ,778 & & \\
\hline Sosyal Destek & & & & 0,80 \\
\hline 7.İş ortamım sakin ve huzurludur. & & & ,577 & \\
\hline 8. İşyerimde diğer çalışanlarla iyi geçinirim. & & & 663 & \\
\hline 9.İ̧̧ arkadaşlarım beni destekler. & & & ,768 & \\
\hline 10.Eğer kötü günümdeysem iş arkadaşlarım beni anlar. & & & 739 & \\
\hline 11.Üstlerim ile iyi geçinirim. & & & 642 & \\
\hline 12. Iş arkadaşlarım ile çalışmaktan zevk alırım. & & & ,761 & \\
\hline Ölçeğin Tümü & & & & 0,70 \\
\hline
\end{tabular}

Faktör analizi verileri incelendiğinde (Tablo 3), 17 ifadeden oluşan orijinal ölçeğin 12 ifadeye indirgendiği görülmektedir. Bu çerçevede, daha önce "Psikolojik Talep" adı altında kavramsallaştıılan boyuttan [toplam 5 ifade] 2 ifade çıkarılmıs, ortaya çıkan yeni boyut "iş̧ Yükü" adı altında 3 ifadeye düşürülmüştür. Benzer biçimde, daha önce "Kontrol" olarak belirtilen boyuttan [toplam 6 ifade] 3 ifade atılmış, yeni boyut "Karar Verme" adı altında 3 ifadeye indirgenmiştir. Sosyal destek boyutunda ise faktör analizi sonrası herhangi bir değişiklik yapılmamış, tüm ifadeler korunmuştur. Bu sonuç, Yıldırım, Taşmektepli 
ve Üzüm (2011) tarafından yürütülen örgütsel stres ölçeği kısa versiyonunun Türkçe 'ye uyarlanması çalışması ile paralellik göstermektedir.

Aynı tabloda her bir boyutun güvenilirlik katsayıları da bulunmaktadır. Cronbach alpha değeri 0,70 ve üzerinde olan ölçeklerin içsel tutarlılığa sahip olduğu, yani ölçeğin güvenilir olduğu ifade edilmektedir. Bu bağlamda, tüm ölçek için hesaplanan güvenilirlik katsayısı 0,70 seviyesindedir. Alt boyutlara bakıldığında, Cronbach alpha değerleri, "iş yükü" alt boyutu için 0,81, "karar verme" alt boyut için 0,68 ve "sosyal destek" alt boyut için 0,80 düzeyindedir. Sonuç itibariyle, indirgenmiş ölçeğin güvenilir olduğu ve "iç tutarlılığa" sahip olduğu bulgusuna ulaşılmıştır. Faktör analizi sonucu ortaya çıkan nihai boyutlar, faktör yükleri ve Cronbach alpha katsayıları Tablo 3'te görülmektedir.

\section{3. Örgütsel Stres Algısında Cinsiyet Temelli Farklılıklar}

Çalışanların stres algılamalarında, cinsiyet itibariyle anlamlı bir farklılı̆ın olup olmadığını tespit etmek amacıyla bağımsız örneklemler t testi uygulanmıştır. Analizde, çalışanların genel stres algısı ve stres ölçeği alt boyutları bazındaki algılamaları ayrı ayrı test edilmiştir (Tablo 4). F istatistikleri, ölçeğin tümü, iş yükü ve karar verme alt boyutları bazında modellerin anlamlı olduklarını ifade etmektedir $(p<0,05)$. $p$ değerleri, ölçeğin tümü $(0,032)$, iş yükü alt boyutu $(0,000)$ ve karar verme alt boyutunda $(0,000)$ stres algısının kadın ve erkek çalışanlar arasında anlamlı bir farklılık gösterdiğini ortaya koymaktadır. Bu bağlamda, H1, H2 ve H3 hipotezleri kabul edilmiştir. Farklılığın tespiti için ortalama değerlere bakıldığında, kadın çalışanların tüm ölçek bazında genel stres algısının $(3,76)$, erkek çalışanlara göre $(3,71)$ daha yüksek olduğu görülmektedir. İ̧̧ yükü yönüyle değerlendirildiğinde, kadın çalışanların $(3,81)$, erkek çalışanlara $(3,68)$ göre daha fazla iş yükü altında olduklarına algılamalarının olduğu tespit edilmiştir. İşüzerindeki otonomilerini ifade eden karar verme alt boyutunda ise kadın çalışanlar $(3,39)$, erkek çalışanlara $(3,51)$ göre işleri üzerinde daha düşük düzeyde karar verme inisiyatiflerinin olduğunu öne sürmektedirler. Sosyal destek alt boyutunda ise analiz sonuçları, kadın ve erkek çalışanlar arasında anlamlı bir farklılı̆ın olmadığını ortaya koymaktadır $(p>0,05)$. Dolayısıyla H4 hipotezi red edilmiştir. Ortalama değerlere bakıldığında, hem erkeklerin hem de kadınların sosyal destek algısının yüksek olduğu görülmektedir. Diğer bir deyimle, hem kadınlar $(3,70)$ hem de erkekler $(3,69)$ uygulamanın yürütüldüğü kurumda, çalışma arkadaşlarıyla iyi ilişkiler içinde olduklarını, destek gördüklerini, diğer çalışanların kendilerini anladıklarını ve iş ortamının bu anlamda huzurlu olduğunu dile getirmektedirler.

Tablo 4. Cinsiyet Bazında Stres Algısı / Bağımsız Örneklemler t Testi Sonuçları

\begin{tabular}{|c|c|c|c|c|c|c|c|}
\hline & & \multicolumn{6}{|c|}{ Levene İstatistiği } \\
\hline & & $\mathbf{N}$ & Ortalama & $\mathbf{F}$ & p değeri & t değeri & p değeri \\
\hline \multirow[t]{2}{*}{ Ölçeğin Tümü } & Kadın & 1012 & 3,76 & \multirow{2}{*}{5,592} & \multirow{2}{*}{0,018} & \multirow{2}{*}{2,144} & \multirow{2}{*}{0,032} \\
\hline & Erkek & 794 & 3,71 & & & & \\
\hline \multirow[t]{2}{*}{ İş Yükü } & Kadın & 1012 & 3,81 & \multirow{2}{*}{30,318} & \multirow{2}{*}{0,000} & \multirow{2}{*}{5,475} & \multirow{2}{*}{0,000} \\
\hline & Erkek & 794 & 3,68 & & & & \\
\hline \multirow[t]{2}{*}{ Karar verme } & Kadın & 1012 & 3,39 & \multirow{2}{*}{5,110} & \multirow{2}{*}{0,024} & \multirow{2}{*}{$-3,940$} & \multirow{2}{*}{0,000} \\
\hline & Erkek & 794 & 3,51 & & & & \\
\hline \multirow[t]{2}{*}{ Sosyal Destek } & Kadın & 1012 & 3,73 & \multirow{2}{*}{0,015} & \multirow{2}{*}{0,902} & \multirow{2}{*}{0,992} & \multirow{2}{*}{0,321} \\
\hline & Erkek & 794 & 3,69 & & & & \\
\hline
\end{tabular}

\subsection{Talep-Kontrol Modeli Çerçevesinde Örgütsel Stres Seviyesi ve Cinsiyet Bazındaki Bulgular}

$\mathrm{Bu}$ aşamada, araştırmanın yürütüldüğü kurumda çalışan personelin talep-kontrol modeli çerçevesinde genel olarak nasıl bir dağılım gösterdikleri (Grafik 1) ve özellikle merak edilen "yüksek iş stresi bölgesinde" (Grafik 2) oluşan yığılmalar belirlenmeye çalışılmaktadır. Grafik 1'deki serpilme incelendiğinde, çalışanların genel olarak yüksek iş yükü algısı (yoğun, hızı ve çok çaba sarf ederek çalışma) içerisinde oldukları anlaşılmaktadır. Buna karşın söz konusu serpilme, karar verme açısından net bir yükseklik veya düşüklük ortaya koyacak yığılma göstermemektedir. 
Yüksek iş stresi bölgesinin analizine geçmeden önce, çalışanların iş yükü ve karar verme otonomilerinin düzeyine bakmak gerekmektedir. Çalışanların tümü bazında değerlendirildiğinde, 1358 çalışanın (\%71) iş yükünü ağır buldukları saptanmıştır. Karar verme açısından bakıldığında ise 902 çalışanın (\%47) işleri üzerinde otonomiye sahip olmadıkları yönünde görüşleri bulunmaktadır. Yüksek iş yükü ve düşük karar verme durumlarının kesiştiği bölge ise "yüksek iş stresini" ifade etmektedir. Dolayısıyla bu aşamada ayrıca yüksek iş stresi bölgesinin sınırları talep-kontrol modeli çerçevesinde netleştirilmiştir. Bunun için 5,00 üzerinden, 3,50 ortalama değer "eşik değer" olarak kabul edilmiştir. Söz konusu eşik değer doğrultusunda talep-kontrol modelinin ana kadranlarının sınırları belirlenmiş, yüksek iş stresi bölgesi netleştirilmiştir. Yüksek iş stresi bölgesi (yüksek iş yükü-düşük karar verme) açısından değerlendirildiğinde (Grafik 2), toplam çalışanların \% 32 'sinin (616 kişi) yüksek düzeyde iş stresi altında faaliyetlerini sürdürdükleri görülmektedir. Bu bölgede yer alan çalışanların cinsiyet profili gözden geçirildiğinde, 616 çalışanın \%63'ünün (386 kişi) kadınlardan, \%33'ünün (203 kişi) ise erkeklerden oluştuğu ortaya çıkmaktadır. [27 kişi (\%4) cinsiyet seçeneğini boş bırakmıştır.] Tüm çalışanlar açısından değerlendirildiğinde ise toplam kadın çalışanların (1012 kişi) \%38'i (386 kişi) yüksek iş stresi bölgesinde yer almaktadırlar. Benzer biçimde, toplam erkek çalışanların (794 kişi) \%26'sının (203 kişi) yüksek iş stresi kadranında yer aldıkları görülmektedir. Bu açıdan bakıldığında, kadınların erkeklere göre daha fazla oranda yüksek iş stresine maruz kaldıkları ortaya çıkmaktadır. Yüksek iş stresi bölgesinde yer alan kadın ve erkek çalışanların kıdem, eğitim, yaş ve çalışma birimi itibariyle dağılımları Tablo 5 'de ayrıca sunulmaktadır.

Tablo 5 incelendiğinde, yüksek iş stresine maruz kalan kadın çalışanların 16 yıl ve üstü kıdem bölgesinde belirgin şekilde yı̆̆ıldıkları, üretim yapan departmanlarda ağılıklı olarak görev aldıkları, ilköğretim ve lise düzeyinde eğitime sahip oldukları ve 30 yaş üstünde oldukları görülmektedir. Erkek çalışanlar açısından değerlendirildiğinde ise kadın çalışanlarla paralel şekilde, yüksek iş stresine maruz kalan erkeklerin üretim yapan departmanlarda ağırlıklı olarak görev aldıkları, ilköğretim ve lise düzeyinde eğitime sahip oldukları ve 30 yaş üstünde oldukları ortaya çıkmaktadır. Erkek çalışanların kıdem açısından belirgin bir yığılma göstermediği anlaşılmaktadır.

Illgili literatür, iş stresinin biyolojik hastalıklara neden olabileceğini sıklıkla vurgulamaktadır (Esch, 2002; Kobayashi, 2004; Siegrist, 2018). Bununla birlikte, sosyal destek mekanizmasının iyi işlemesi halinde, yüksek iş stresinin kişide hastalıklara yol açma riskinin zayıfladığı ifade edilmektedir. Bu bağlamda, araştırmanın yürütüldüğü kurumda yüksek iş stresi bölgesinde yer alan çalışanların, sosyal destek algılarının yüksek olması nedeniyle (Tablo 4) daha zayıf intimalle biyolojik hastalıklarla karşılaşabilecekleri düşünülmektedir. Dolayısıyla, kurumdaki sosyal ağ ve dayanışma kültürünün, yüksek iş stresinin beraberinde getirdiği bazı olumsuz sonuçları engelleyebileceği sonucuna varılmaktadır.

\section{Grafik 1. Tüm Çalışanlar Bazında Stres Düzeyi}

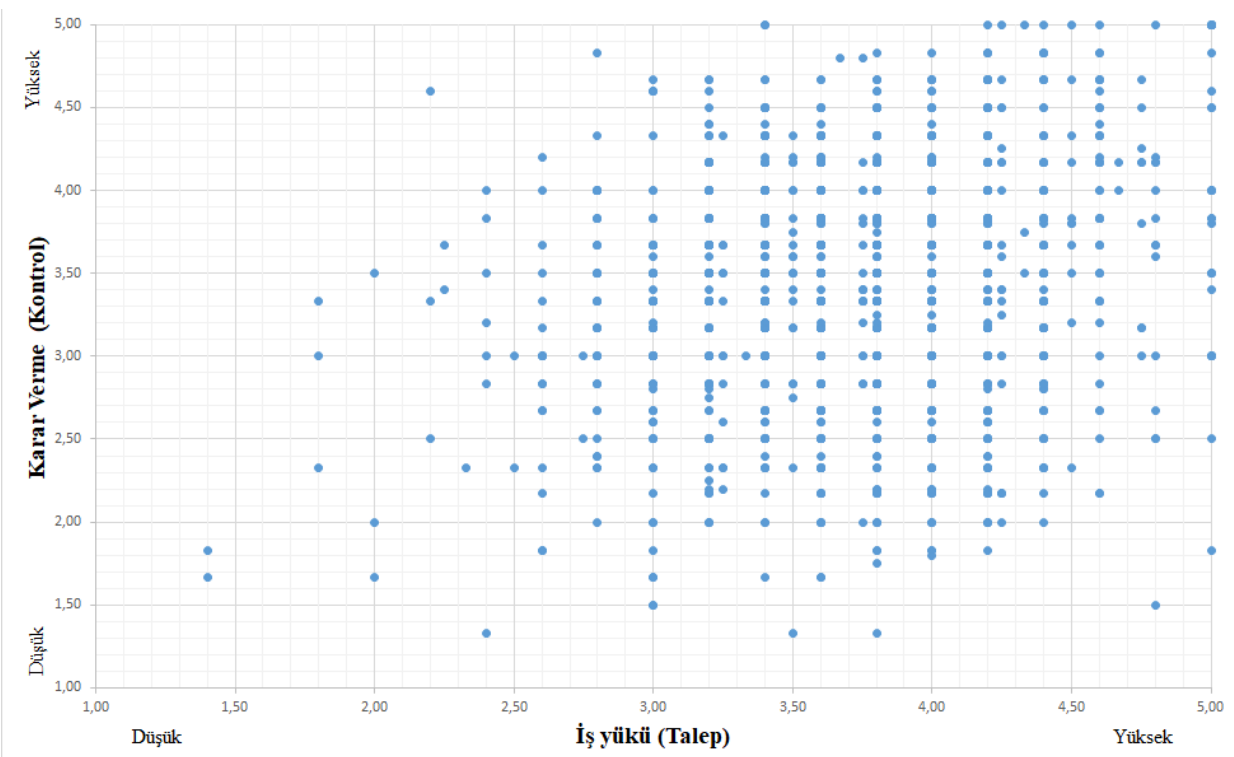


Grafik 2. Yüksek İş Stresi Bölgesi

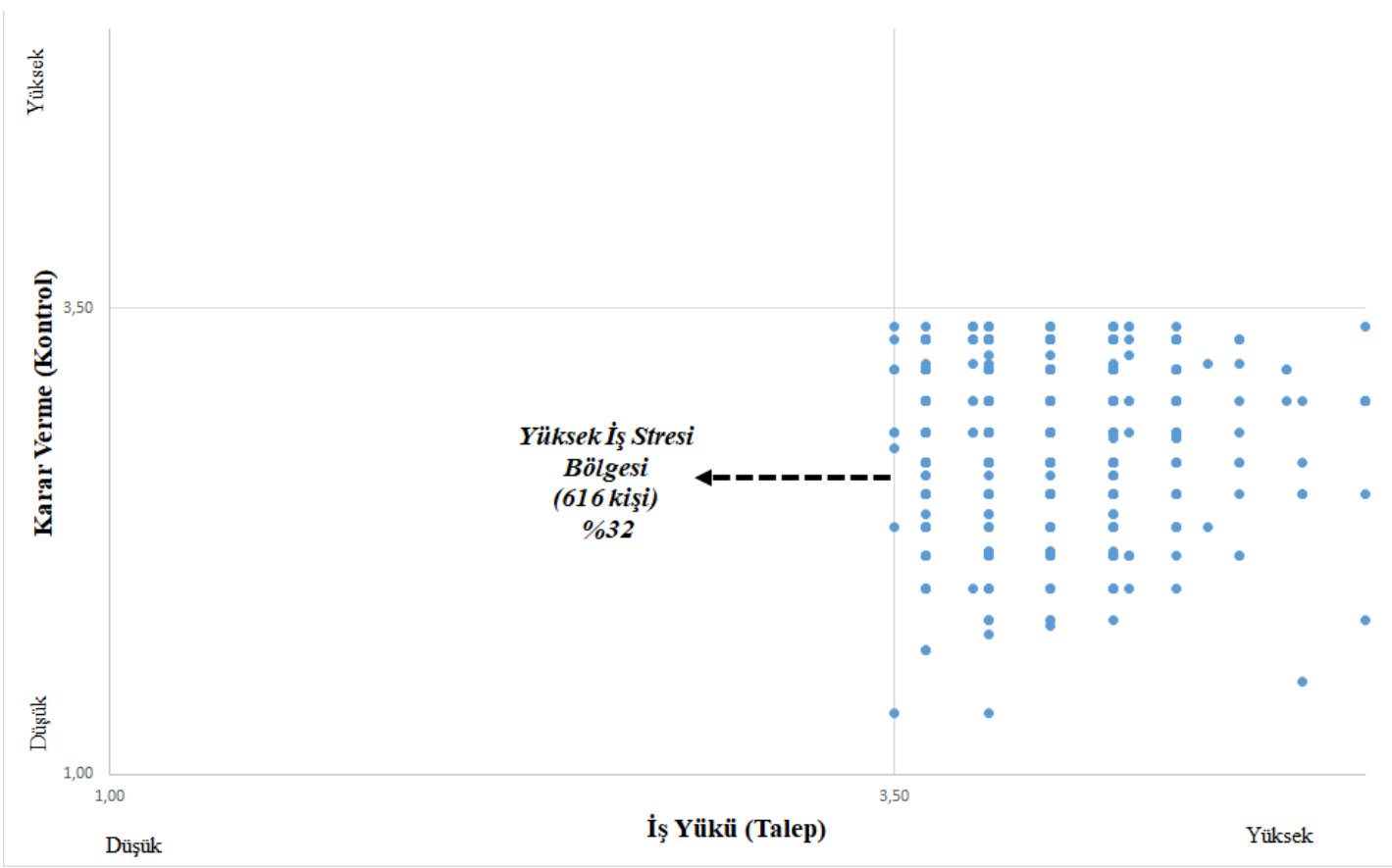

Tablo 5. Yüksek İş Stresi Bölgesinde Yer Alan Kadın ve Erkek Çalışanların Karşılaştırmalı Profili

\begin{tabular}{|c|c|c|c|c|c|}
\hline & & \multicolumn{2}{|c|}{ Kadın } & \multicolumn{2}{|c|}{ Erkek } \\
\hline & & $\begin{array}{c}\text { Kişi } \\
\text { Sayısı }\end{array}$ & $\begin{array}{c}\text { Oran } \\
(\%)\end{array}$ & Kişi Sayısı & $\begin{array}{c}\text { Oran } \\
(\%)\end{array}$ \\
\hline \multirow{6}{*}{ Kıdem } & 1 yıla kadar & 77 & 20 & 37 & 18 \\
\hline & $1-5 \mathrm{yıl}$ & 54 & 14 & 48 & 24 \\
\hline & $6-10$ yıl & 73 & 19 & 25 & 12 \\
\hline & $11-15$ yıl & 43 & 11 & 31 & 15 \\
\hline & 16 yıl ve üstü & 130 & 34 & 53 & 26 \\
\hline & Cevapsiz & 9 & 2 & 9 & 4 \\
\hline \multirow{7}{*}{ Eğitim } & ilköğretim & 199 & 52 & 76 & 37 \\
\hline & Lise & 127 & 33 & 111 & 55 \\
\hline & Meslek Yüksek Okulu & 13 & 3 & 4 & 2 \\
\hline & Üniversite (Lisans) & 42 & 11 & 10 & 5 \\
\hline & Yüksek Lisans & 1 & 0.5 & 1 & 0.5 \\
\hline & Doktora & - & - & - & - \\
\hline & Cevapsiz & 4 & 0.5 & 1 & 0.5 \\
\hline \multirow{6}{*}{ Yaş } & 20 yaşına kadar & - & - & - & - \\
\hline & $21-30$ yaş & 71 & 18 & 48 & 24 \\
\hline & $31-40$ yaş & 160 & 41 & 74 & 36 \\
\hline & $41-50$ yaş & 148 & 38 & 75 & 37 \\
\hline & 51 ve üstü & 3 & 1 & 1 & 1 \\
\hline & Cevapsiz & 4 & 1 & 5 & 2 \\
\hline \multirow{3}{*}{ Çalışma Birimi } & Üretim Birimleri & 345 & 89 & 174 & 86 \\
\hline & Idari Birimler & 34 & 9 & 20 & 10 \\
\hline & Cevapsiz & 7 & 2 & 9 & 4 \\
\hline
\end{tabular}




\subsection{Cinsiyet Bazında Stres Kaynakları}

Araştırmanın bu aşamasında, kadın ve erkek çalışanlarda strese neden olabilecek kurumsal faktörlerin neler olabileceği sorgulanmaktadır. Söz konusu faktörler, kurum içi değişkenlerle ilişkilendirilmektedir. Kurum dışı ya da çevresel stres unsurları bu sorgulamaya dâhil edilmemiştir. Bu amaçla, 640 ankette yanıtı verilen açık uçlu soru çerçevesinde çalışanların ifade etmiş oldukları görüşler sınıflandırılmıştır. 640 ankette açık uçlu soruya yanıt veren çalışanların 365'i kadın, 275'i erkeklerden oluşmaktadır. Söz konusu ifadeler teker teker okunmuş, ifadelerde frekans oluşturabilecek anahtar kelimeler gruplandırılmış ve stres kaynağı olarak kodlanmıştır. Her bir çalışan, genel olarak birden fazla konuda görüş beyan etmektedir. Sözgelimi, ilgili kişi ücret düzeyi ile ilgili görüşlerinin yanı sıra fiziksel çalışma koşulları ya da iş yükü dengesi üzerine de eleştirilerini sıralayabilmektedir. Dolayısıyla çalışanlar, üzerlerinde baskı yaratan birden çok kurumsal problemi dile getirmekte ve olası stres kaynaklarına işaret etmektedirler. Yapılan kodlamada, 13 ayrı anahtar sorunun (stres faktörü) varlığı tespit edilmiştir. Stresle ilintili anahtar sorunların ne anlama geldiği ayrıca aşağıda açıklanmaktadır. İlgili stres faktörlerine ait genel ve cinsiyet bazında frekans dağılımları Tablo 6'da görülmektedir.

Tablo 6. Cinsiyet Bazında Stres Faktörleri

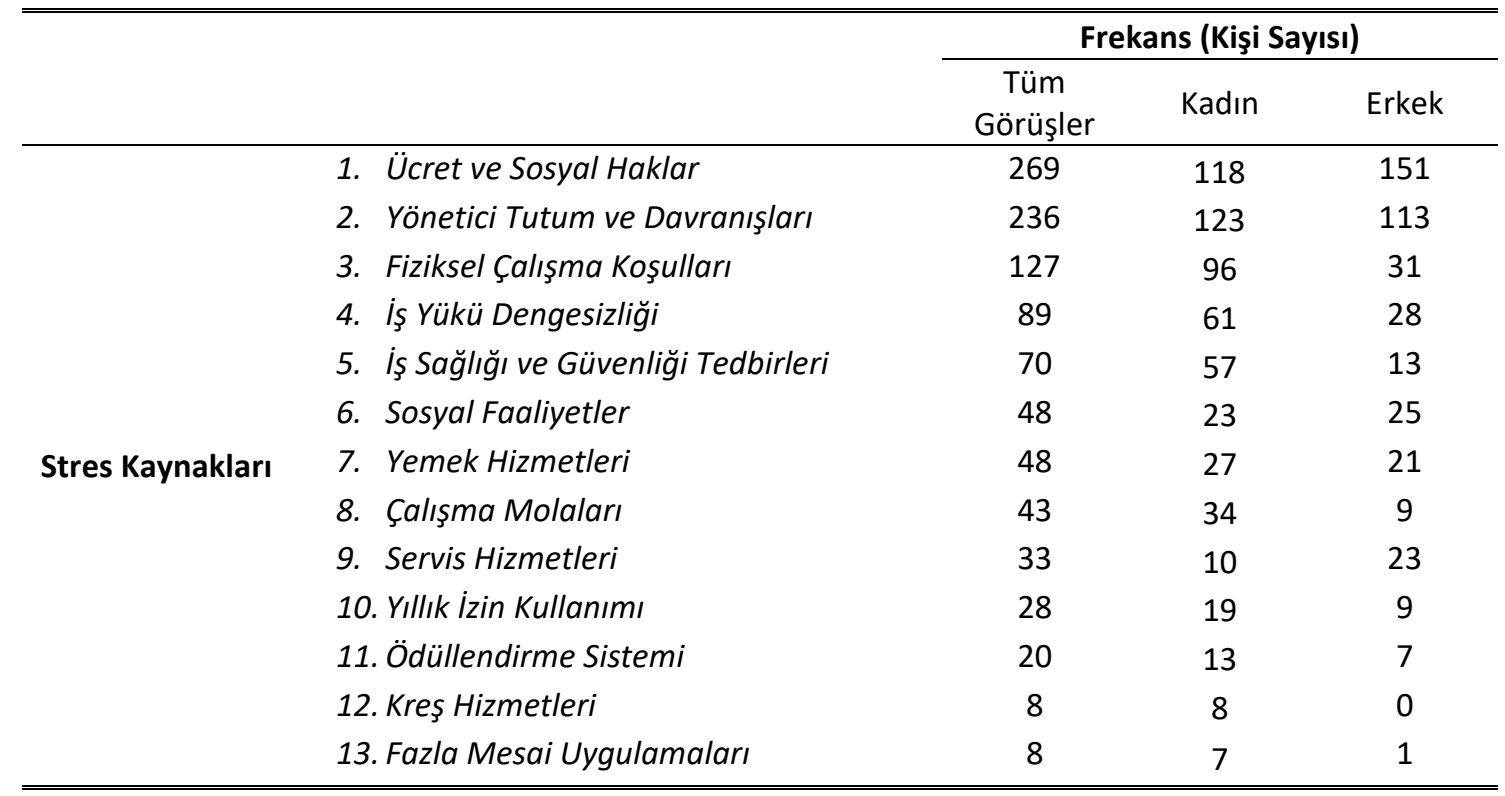

Ücret ve Sosyal Haklar: Yeni giren çalışanların, kıdemli olan çalışanlara çok yakın düzeyde ücret almaları, ücretlemede adil olmayan uygulamalar, banka promosyonlarının ücretlere ilave olarak verilmemesi, sendikaların işyerinde iş̧̧ileri koruyucu önlemler almaması, kıdem tazminatı ödemelerinde aksamalar, uzun deneme süresi (4 ay) nedeniyle hak mahrumiyeti.

Yönetici Tutum ve Davranış/arı: Yöneticilerin çalışanlar üzerinde oluşturdukları baskı, sözlü hakaret, aşağılama, çalışanlara eşit davranmama, azarlama, çalışanların fikirlerine önem vermeme, çalışanlardan geribildirim almama, çalışanlara saygı göstermeme, yönetici yeteneklerinin istenen seviyede olmaması.

Fiziksel Çalışma Koşulları: Havalandırma ve ısıtma problemleri, dinlenme mekânlarının kısıtılığı, emzirme odalarının eksikliği, üretim alanlarında gürültü, bazı departmanlara yerleştirilen kamera sistemlerinin yarattığı rahatsızlıklar.

İ̧ Yükü Dengesizliği: Hedef üretim adetlerinin yarattığı baskı, personel eksikliğinden kaynaklanan kişi başı üretim adetlerinin fazlalığı, zorunlu fazla mesai uygulamaları, fazla mesainin getirdiği iş-yaşam dengesinde bozulmalar. 
IŞ Sağlığı ve Güvenliği Tedbirleri: İş sağlığı ve güvenliği ekipmanlarının (maske, koruyucu önlük, gözlük) yetersizliği, hijyenik olmayan fiziksel çalışma mekanları, işyeri doktoru hizmetindeki aksamalar, işyerinde sağlık testlerinin (kan, idrar vb.) yapılmıyor olması, atık giderlerinin yarattığı kötü koku, acil çıkış kapılarındaki eksiklik, hijyenik olmayan yemekler, iş ayakkabılarının çalışma için uygun olmaması.

Sosyal Faaliyetler: Kurumda uygulanmakta olan yemek, piknik, gezi, sosyal klüp vb. sosyal aktivitelerin yetersizliği.

Yemek Hizmetleri: Yemeklerin miktar olarak yetersizliği, soğuk yemek verilmesi, yemek çeşitliliğinin sınırlı olması, yemeklerin hijyenik olmaması, yemek molasının süre olarak yetersizliği.

Çalışma Molaları: Mola için ayrılan sürelerin yetersizliği, bazı bölümlerde mola uygulamasının olmaması ve buna bağlı algılanan adaletsizlik.

Servis (Ulaşım) Hizmetleri: Servis saatlerinden ve güzergâhlarından duyulan memnuniyetsizlik, servis şoförlerinin davranış bozuklukları, servis araçlarının teknik yetersizlikleri (klima vb.), servis araçlarının yolcu taşıma kapasitesinin yetersizliği.

Yıllık İin Kullanımı: Yaz aylarında kullandırılan yıllık izin süresinin (iki hafta) yetersiz bulunması, yıllık izinlerin istenildiği zaman kullanılamaması, biriken yıllık izin sürelerinin kullandırımaması.

Ödüllendirme Sistemi: Ödüllendirme sistematiğinde görülen aksaklıklar, ödül miktarlarının yetersiz bulunması, ödüllendirmede adaletsiz uygulamalar.

Kreş Hizmetleri: Kreşlerde kamera olmaması ve ebeveynlerin buna bağlı duydukları endişe, kreşlerde çocuklara yönelik sosyal aktivitelerin yetersiz görülmesi, çocuklara gösterilen ilginin yetersizliği.

Fazla Mesai Uygulamaları: Çalışanlardan zorunlu fazla mesai talebinde bulunma, fazla mesaiye kalmak istemeyen çalışanlara uygulanan baskı, normalin üstünde sıklıkta fazla mesai uygulamaları ve buna bağlı iş-yaşam dengesi problemlerinin ortaya çıkması, vardiya sisteminin olmaması.

Tablo 6 incelendiğinde, öncelikle ücretleme ve sosyal hakların edinimi konusunda çalışanların problem yaşadıkları görülmektedir. Açık uçlu soru kapsamında yazılan ifadeler okunduğunda, kıdemli çalışanlar ile yeni işe giren personel arasında belirgin bir ücret farklılı̆ıının olmamasını eleştirdikleri fark edilmektedir. Kıdemi nispeten daha yüksek olan çalışanlar bu durumu "adaletsizlik" olarak nitelemektedirler. Adil olarak algılanmayan bu uygulama, çalışanlar üzerinde psikolojik baskı yaratmaktadır. Buna ilave olarak, çalışanların sosyal haklarını (sendikaların işlevlerini yerine getirmiyor olması, kıdem tazminatlarııın alınıp işten çıkamama durumu, deneme süresinin uzunluğuna bağlı hak mahrumiyeti) alamıyor olmaları söz konusu baskının şiddetini artırmakta, stres oluşumuna zemin hazırlamaktadır. Diğer taraftan, kurumda özellikle alt kademe yöneticilerin tutum ve davranışları ile çalışanlar üzerinde baskı oluşturdukları görülmektedir. Sözlü hakaret, aşağılama, çalışanlara eşit davranmama, azarlama, çalışanların fikirlerine önem vermeme, çalışanlardan geribildirim almama veya çalışanlara saygı göstermeme yönündeki davranışların, çalışanların moral düzeyini düşürdüğü ve stres yarattığı anlaşıımaktadır. Bu durumun, yöneticilerin yönetsel becerilerinin eksik olması ile açıklanabilmesi mümkündür.

Fiziksel çalışma koşullarının da ciddi şekilde stres yaratabilecek bir potansiyel gösterdiği görülmektedir. Üretim alanlarında havalandırma sorunlarının yaşanması, kış aylarında ısıtma problemlerinin olması, temizlik hizmetlerinin yetersizliği çalışanlar üzerinde olumsuz etkiler yaratmaktadır. Dinlenme mekânları veya emzirme odaları gibi zaruri ve insani alanların yetersizliği özellikle kadın çalışanlar üzerinde daha fazla negatif etki yaratmaktadır.

Diğer taraftan, iş yükü açısından da çalışanların zorluklar ile karşılaştıkları görülmektedir. Nitel veriler incelendiğinde, çalışanların günlük üretim adetlerini yakalamakta zorlandıkları ve alt kademe yöneticilerin (usta, ustabaşı) hedef üretim adetlerine ulaşma noktasında çalışanlara baskı yaptıkları anlaşılmaktadır. İade edilen görüşlerden yola çıkarak, kurumda personel yetersizliğinin olduğu ve bunun da çalışan başına iş yükünü artırdığı sonucuna varılmaktadır. Üretim hedeflerini yakalamak adına "zorunlu" fazla mesai uygulamaları ise çalışanların iş yaşam dengesini bozucu etkiler yaratmaktadır. İ̧̧ükü ağılığı ve buna bağlı ortaya çıkan negatif sonuçların çalışanların stres düzeyleri üzerinde etkili olduğu sonucuna varılabilmektedir. 
Benzer biçimde, iş sağlığı ve güvenliği ile ilişkili konularda da çalışanlar olumsuz koşulları dile getirmektedirler. Çalışanlar tarafından ifade edilen, iş sağlığı ve güvenliği ekipmanlarının (maske, koruyucu önlük, gözlük) yetersizliği, hijyenik olmayan fiziksel çalışma mekânları, işyeri doktoru hizmetindeki aksamalar, işyerinde sağlık testlerinin (kan, idrar vb.) yapılmıyor olması, atık giderlerinin yarattığı kötü koku, acil çıkış kapılarındaki eksiklik, hijyenik olmayan yemekler, sağlıksız havalandırma koşulları, iş ayakkabılarının çalışma için uygun olmaması gibi hususların, strese neden olabilecek kurumsal faktörler arasında yer aldığı düşünülmektedir.

Stres yaratma olasılığı bulunan diğer faktörlere bakıldığında çalışanların, sosyal faaliyetleri yeterli bulmadıkları, yemek hizmetleri ile ilgili sorunlar yaşadıkları görülmektedir. Özellikle her gün iki defa yararlanılan servis hizmetinin günlük tempoda agresif durumlara yol açtı̆̆ı ve münakaşalara neden olduğu anlaşıımaktadır. Yıllık izin kullanımı ve zorunlu fazla mesai uygulamalarının da bilhassa iş-yaşam dengesini bozucu etkilerinin olduğu sıklıkla dile getirilmektedir. Ödüllendirme boyutunda ise adil olmayan ödül uygulamalarının çalışanları baskı altına aldığı tahmin edilmektedir.

Kadın ve erkek çalışanlar ekseninde değerlendirildiğinde, strese neden olan faktörlerin algılanmasında benzerlik ve farklııkların ortaya çıktığı görülmektedir. Ücret ve sosyal haklar, yönetici tutum ve davranışları, sosyal faaliyetler, yemek hizmetleri ve ödüllendirme sistemi konularında, kadın ve erkeklerin stres faktörlerini benzer biçimde algıladıkları tespit edilmiştir. Buna karşın, kadın çalışanların bazı alanlarda kendilerini daha fazla baskı ve stres altında hissettikleri anlaşılmaktadır. Strese neden olan faktörlerden, iş yükü fazlalığı, fiziksel çalışma koşullarının ortaya çıkardığı sorunlar, iş sağlığı ve güvenliği tedbirlerinin yetersizliği, çalışma molalarının yetersizliği kadın çalışanları erkeklere nazaran daha sert biçimde etkilemektedir. Erkekler ise servis hizmetleri ile ilgili problemlere kadınlara nazaran daha duyarlı bakmaktadırlar. Söz konusu bulgulardan hareketle, örgütsel stres faktörlerinin değerlendirilmesinde ve çözüm önerilerinin geliştirilmesinde cinsiyet temelli ayrıştırmaların yapılması bir zorunluluk olarak ortaya çıkmaktadır.

\section{Sonuç ve Tartışma}

Araştırmada öne çıkan en genel bulgu, çalışanların önemli bir kısmının (\%32) "yüksek iş stresi bölgesinde" faaliyetlerini yürütüyor olmalarıdır. Bu bulguyu destekleyecek şekilde, çalışanların büyük bir bölümünün mevcut iş yükünden rahatsız olduğu ve kendi işleri üzerinde karar verme inisiyatifine (otonomi) sahip olmadıkları ortaya çıkmaktadır. Buna karşın, uygulamanın yürütüldüğü kurumda çalışanların sosyal destek algısının yüksek olduğu görülmektedir. Diğer bir deyimle, bireyin diğer çalışanlardan aldığı sosyal destek, bireye gösterilen anlayış, birlikte çalışmaktan duyulan zevk ya da üstler ile iyi geçinme durumlarının arzu edilen seviyede olduğu anlaşılmaktadır. Dolayısıyla, bilhassa yüksek iş stresinin neden olabileceği biyolojik hastalıkların, sosyal destek mekanizması aracılığı ile göreli olarak engellenebileceği varsayılmaktadır.

Araştırmanın ana sorunsalı çerçevesinde, örgütsel stres algılamasında "cinsiyet temelli" farklılıkların var olduğu bulgusuna ulaşılmıştır. Kadın ve erkekler arasında, stres algılamasının farklı olabileceği bulgusu, literatürdeki çeşitli araştırma bulguları (Mallach, 1996; Tinuke, 2015; Narayahan vd., 1999) ile benzerlik göstermektedir. Daha spesifik düzeyde değerlendirildiğinde, örgütsel stres düzeyinin kadın çalışanlarda, erkek çalışanlara oranla daha yüksek olduğu görülmüştür. Bu sonuç, Omolayo (2012) ve Sliskovic ile Sersic (2011) tarafından yürütülen araştırma bulguları ile paralel nitelik göstermektedir. Örgütsel stres ölçeğine ait alt boyutlar (iş yükü, karar verme ve sosyal destek) bazında değerlendirildiğinde, iş yükü algılamasında kadın ve erkek çalışanlar arasında anlamlı bir farklılığın bulunduğu tespit edilmiştir. Kadın çalışanlar, erkek çalışanlara nazaran daha fazla iş yükü altında olduklarını ifade etmektedirler. Benzer biçimde, karar verme yönüyle de kadın ve erkek çalışanlar arasında anlamlı bir farklılığın olduğu saptanmıştır. Buna göre, erkek çalışanlar, kadın çalışanlara göre işlerinde karar verme inisiyatiflerinin daha fazla olduğunu ifade etmektedirler. Buna karşın, örgütsel stres algısının, cinsiyet temelinde farklııık gösterdiği yönündeki mevcut bulgu, Gelyllensten ve Palmer (2005) ile Rout (1999) tarafından yürütülen araştırmalarla benzer nitelik göstermemektedir. Sosyal destek mekanizması açısından ise cinsiyet bazında herhangi bir algı farklılığının olmadığı görülmüştür. Hem kadın hem de erkek çalışanlar, sosyal destek unsurlarının destekleyici yönüne atıfta bulunmaktadırlar. Bu çalışmada, sosyal destek alt boyutu çerçevesinde ulaşılan bulgu, Tores vd. (2013) 
tarafından ortaya konulan "sosyal destek algısı kadınlarda, erkeklere oranla örgütsel stresi azaltmada daha etkili sonuçlar yaratmaktadır" bulgusu ile uyum göstermemektedir.

Konu, strese yol açan kaynaklar açısından değerlendirildiğinde, ücret ve sosyal hakların ödenmesindeki sorunların, yöneticilerin negatif tutum ve davranışlarının, fiziksel çalışma koşullarındaki uygunsuzlukların, iş yükü dengesizliğinin, iş sağlığı ve güvenliği tedbirlerindeki aksamaların çalışanlarda stres yaratan ana etmenler olduğu sonucuna varılmaktadır. Buna ilave olarak, sosyal faaliyetlerin yetersizliği, yemek ve servis hizmetleri ile çalışma molası pratiklerinin, örgütsel stresi ikincil derecede artıran faktörler olduğu görülmektedir.

Diğer taraftan, açık uçlu soruya verilen yanıtlardan elde edilen frekans dağılımları incelendiğinde, stres faktörlerinin kadın ve erkek çalışanlar arasında birtakım benzerlikler ve farklılıklar gösterdiği bulgusuna ulaşılmıştır. Ücret ve sosyal haklar, yönetici tutum ve davranışları, sosyal faaliyetler, yemek hizmetleri yönüyle kadın ve erkek çalışanlar açısından belirgin bir algı farklılı̆ının olmadığı anlaşılmaktadır. Buna karşın, fiziksel çalışma koşullarındaki yetersizliklerin, iş yükü dengesizliklerinin, iş sağlığı ve güvenliği tedbirlerindeki eksikliklerin, çalışma molası ve yıllık izin uygulamalarının kadın çalışanlarda, erkeklere göre daha fazla stres yarattığı sonucuna ulaşıımıştır. Servis hizmeti uygulamasında ise erkeklerin daha tepkisel olduğu ve kadınlara nazaran bu konuda daha fazla stres yaşadıkları sonucuna varılmaktadır. Bu noktada, bazı stres faktörlerinin "kadına özgü" şekilde yorumlanması gerektiği düşünülmektedir. Örneğin, iş yükü fazlalığı, iş sağlığı ve güvenliği koşullarının ağırlığı, mola sürelerinin kısalığı kadına daha fazla fiziksel efor yüklediğinden, kadın çalışanların erkeklere göre konuya daha fazla tepkisel yaklaştıkları anlaşılmaktadır. Benzer biçimde, yıllık izin süresindeki kısalığın da "iş-yaşam dengesi" açısından kadını, erkeğe göre daha fazla güç durumda bırakabileceği düşüncesi hâkimdir.

Özellikle stres kaynakları açısından değerlendirildiğinde, örgütsel düzeyde strese neden olan unsurların ortadan kaldırımasına dönük önlemler kritik nitelik taşımaktadır. Bu bağlamda, öncelikle uygulamanın yürütüldüğü kurumda, çalışanların negatif yönlü örgütsel adalet algısı değiştirilmelidir. Ücret ve sosyal hakların kullanımı çerçevesinde yaşanan sorunlar giderilmelidir. Yeni işe başlayanlar ile kıdemli çalışanlar arasındaki ücret farklııkları, kıdemli çalışanlar lehine artırımalıdır. Diğer bir deyimle, yeni işe başlayanlar ile uzun süre kurumda çalışan personel arasında, ücret yönüyle bir kıdem farkı yaratılmalıdır. Diğer taraftan, örgütte uygulanmakta olan ve yeni işe girenler için öngörülen 4 aylık deneme süresi, piyasadaki benzer işletmelerle karşılaştırıldığı zaman adalet duygusunu zedelemektedir. Dolayısıyla, deneme süresi çalışanlar lehine kısaltılmalıdır ya da piyasa ile uyumlu hale getirilmelidir.

Stres düzeyini azaltmak için alınabilecek diğer bir önlem, kurumdaki yönetsel becerilerin geliştirilmesidir. Çalışanlarda gerginliğe neden olan yönetici tutumları ortadan kaldırılmalıdır. Çalışanları azarlamak, hakaret etmek, aşağılamak biçiminde ortaya çıkan yönetici davranışlarının, yönetici geliştirme eğitim programları ile değiştirilmesi gerekmektedir. Çalışanlar arasında adil olamamak, çalışanlara saygı göstermemek ve çalışanların fikirlerine önem vermemek şeklinde ifade edilen yönetici davranışlarının çeşitli eğitim programları ile düzeltilmesi gerekmektedir. Özellikle alt kademe yöneticilerde (usta, ustabaşı) ortaya çıkan söz konusu tutum ve davranışların yakından takip ve kontrol edilmesi şart görünmektedir.

Uygulamanın yürütüldüğü kurumun üretim departmanında çalışanların yoğun bir iş yükü ve günlük üretim hedefi ile karşı karşıya oldukları görülmüştür. Söz konusu üretim baskısı, çalışanların stres düzeyi üzerinde etkili görünmektedir. Dolayısıyla, üretim hedefleri, çalışanların iş yükü dengesi ve kapasitesi ölçüsünde revize edilmelidir. Daha fazla üretim için işletme dışı kaynaklardan personel temin edilmeli, çalışan sayısı güçlendirilmelidir. Üretimi artırmak adına gerçekleştirilen "zorunlu" fazla mesai uygulamaları kaldııımalıdır. Zorunlu fazla mesai uygulamaları diğer taraftan çalışanların iş-yaşam dengesini de negatif gönde etkilemektedir.

Yüksek düzeyde iş stresinin, biyolojik hastalıklara neden olabileceği teorik açıklamalarda ifade edilmişti. Sosyal destek algısının kurum içinde pozitif olduğu bulgusundan hareketle, mevcut sosyal destek algısının güçlendirilmesi adına, kurum bünyesinde planlanan ve yeterli olmadığı ifade edilen "sosyal aktivitelere" ağılık verilmesinde fayda bulunmaktadır. Piknik, spor karşılaşmaları, yemek vb. 
organizasyonların, mevcut sosyal destek algısını güçlendirmek açısından, daha sık uygulanması olumlu sonuçlar verebilecektir.

Son olarak, kurumda çalışma molası uygulamaları ile mesai saati uygulamalarının revize edilmesi gereği ortaya çıkmaktadır. Çalışanların beyan etmiş olduğu görüşler çerçevesinde, üretimle bağlantılı bazı departmanlarda mola saatlerinin olmamasının, fiziksel ve psikolojik baskı unsuru olduğu ifade edilmektedir. Mesai saati uygulamalarının ise iş-yaşam dengesini bozucu etkilerinin olduğu sıklıkla dile getirilmektedir. Bu bağlamda, mola ve mesai saati uygulamalarının, çalışanların iş-yaşam dengesini gözetecek biçimde revize edilmesi gerekmektedir.

\section{Araştırmanın Kısıtları ve Gelecek Araştırmalar İçin Öneriler}

Stres kavramı göreli bir içerik ihtiva etmektedir ve kişiye, koşullara ya da kuruma özgü olarak değişkenlik gösterebilmektedir. Söz konusu değişkenlik, araştırmanın en önemli kısıtını oluşturmaktadır. Dolayısıyla, bu araştırma verilerinden elde edilen bulgular, araştırmanın yürütüldüğü kurumun o dönemki koşullarına ve araştırmanın yürütüldüğü kişilerin karakteristiklerine büyük oranda bağlıdır. Bu bağlamda, genel geçer yargılara varmak mümkün görünmemektedir.

Gelecek araştırmalara başlangıç noktası oluşturması açısından, tekstil endüstrisi dışında farklı bir endüstriden veri toplanarak karşılaştırma yapılması planlanmaktadır. Böylelikle, örgütsel stres algılamasının ve stres kaynaklarının farklı bir endüstride nasıl göründüğü tespit edilebilecektir. Sözgelimi, otomotiv endüstrisinde iş sağlığı ve güvenliği tedbirlerinin, tekstil endüstrisine göre daha sıkı kurallara bağlı olduğu noktasından hareketle, iş sağlığı ve güvenliği tedbirlerinin yetersizliğine bağlı bir örgütsel stres durumunun ortaya çıkma intimalinin düşük olabileceği varsayılmaktadır.

\section{Kaynaklar}

Barboza, C., \& Thomas, B. (2017). Gender difference in organisational role stress: A study of employees in IT sector in Mangalore City. Indian Journal of Commerce \& Management Studies, 8(3), 1-6.

Cahlikova, J., Cingl, L., \& Levely, I. (2016). How stress affects performance and competitiveness across gender. Academy of Sciences of the Czech Republic Economics Institute, Discussion Paper Series.

Calvarese, M. (2015). The effect of gender on stress factors: An exploratory study among university students. Social Sciences, 4, 1171-1184.

Chaturvedi, V. (2011). A Study on gender differences with relation to occupational stress among faculties in management colleges of private and government institutes: A study with reference to Management Colleges in NCR. International Journal of Business Management and Economic Research, 2(2), 168-172.

Efthim, P., Kenny, M., \& Mahalik, J. (2001). Gender role stress in relation to shame, guilt, and externalization. Journal of Counseling \& Development, 79, 430-438.

Eisler, R., \& Blalock, J. (1991). Masculine gender role stress: Implications for the assessment of men. Clinical Psychology Review, 11, 45-60.

Gyllensten, K., \& Palmer, S. (2005). The role of gender in workplace stress: A critical literature review. Health Education Journal, 64(3), 271-288.

Kalaycı, Ş. (2005). SPSS uygulamalı çok değişkenli istatistik teknikleri. Ankara: Asil Yayın Dağıtım.

Karasek, R. A. (1979). Job demands, job decision latitude, and mental strain: Implications for job redesign, Administrative Science Quarterly, 24(2), 285-308.

Karasek, R. A., Traintis, K. P., \& Chaudhry, S. S. (1982). Coworker and supervisor support as moderators of associations between task characteristics and mental strain. Journal of Occupational Behaviour, 3, 181-200.

Karasek, R. A., \& Theorell, T. (1990). Healthy work, stress, productivity and reconstruction of work in life. New York Basic Books.

Fumio Kobayashi, F. (2004). Job stress and stroke and coronary heart disease, Journal of the Japan Medical Association, $47(5), 222-226$. 
Lim, V. K. G., \& Teo, T. S. H. (1996). Gender differences in occupational stress and coping strategies among IT personnel. Women in Management Review, 11(1), 20-28.

Mallach, C. S. (1996). Coping with stress amongst males and females in professional occupations. University of South Africa, Master Thesis.

Miller, K., Greyling, M., Cooper, C., Lu, L., Sparks, K., \& Spector, P. E. (2000). Occupational stress and gender: A crosscultural study. Stress Medicine, 16, 271-278.

Narayanan, L., Menon, S., \& Spector, P. E. (1999). Stress in the workplace: A comparison of gender and occupations. Journal of Organizational Behavior, 20(1), 63-73.

Omolayo, B. (2012). Effect of gender and status on job stress among police officers in Ekti State of Nigeria. Bangladesh e-Journal of Sociology, 9(1), 38-42.

Rodriguez, I., Bravo, M. J., Peiro, J. M., \& Schaufeli, W. (2001). The demands-control-support model, locus of control and job dissatisfaction: A longitudinal study. Work and Stress, 15(2), 97-114

Rout, U. (1999). Gender differences in stress, satisfaction and mental wellbeing among general practitioners in England. Psychology, Health \& Medicine, 4(4), 345-354.

Santos, A., \& Eger, A. (2014). Gender differences and predictors of workplace deviance behaviour: The role of job stress, job satisfaction and personality on interpersonal and organisational deviance. International Journal of Management Practice, 7(1), 19-32.

Shen, C. Y. (2014). The relative study of gender roles, and job stress and adversity quotient. The Journal of Global Business Management, 10(1), 19-32.

Selye, H. (1976). The stress of life. New York: McGraw-Hill.

Siegrist, J., \& Li, J. (2018). Work stress and the development of chronic diseases. International Journal of Environmental Research and Public Health, 15, 1-3.

Sliskovic, A., \& Sersic, D. M. (2011). Work stress among university teachers: Gender and position differences. Arh Hig Rada Toksikol, 62, 299-307.

Tandon, J. K., Mahaur, C., \& Gupta, A. (2014). Effect of age and gender on occupational stress: A study on teaching fraternity. International Journal of Engineering Technology, Management and Applied Sciences, 2(2), 41-46.

Tanrıkulu, C. (2017). Sex and gender identity differences in psychological job outcomes among salespeople. Review of Business Management, 19(66), 499-519.

Theorell, T., Perski, A., Akerstedt, T., Sigala, F., Ahlberg-Hulten, G., Svensson, J., \& Eneroth, P. (1988). Changes in job strain in relation to changes in physiological state: A longitudinal study. Scandinavian Journal of Work and Environmental Health, 14(3), 189-196.

Tinuke, M. F. (2015). Gender disparities in antecedents, manifestations and corollaries of workplace stress. Journal of Human Resource Management, 3(6), 60-67.

Torres, P. R., Padilla, R. A. A., \& Simó, M. J. M. (2013). Job stress across gender: The importance of emotional and intellectual demands and social support in women. International Journal of Environmental Research and Public Health, 10, 375-389.

Türkmen, A. (2015). Sağlık işletmelerinde örgütsel stresin işgücü performansına etkilerinin araştırılması: Bandırma Devlet Hastanesi Örneği. Okan Üniversitesi Sağlık Bilimleri Enstitüsü, Yayınlanmamış Yüksek Lisans Tezi, İstanbul.

Esch, T., Stefano, G.B., Fricchione, G.L., \& Benson, H. (2002). Stress-related diseases: A potential role for nitric oxide. Medical Science Monitor: International Medical Journal of Experimental and Clinical Research, 8(6), 103-118.

Vagg, P. R., Spielberger, C. D., \& Wasala, C. F. (2002). Effects of organizational level and gender on stress in the workplace. International Journal of Stress Management, 9(4), 243-255

Wu, Y. C., \& Shih, K. Y. (2010). The effects of gender role on perceived job stress. The Journal of Human Resource and Adult Learning, 6(2), 74-79.

Yıldırım, Y., Taşmektepligil, M. Y., \& Üzüm, H. (2011). Kısa versiyon örgütsel stres ölçeğinin türkçeye uyarlanması: Geçerlilik ve güvenirlik çalışması. Selçuk Üniversitesi Beden Eğitimi ve Spor Bilim Dergisi, 13(1), 103-108. 
This Page Intentionally Left Blank 